\title{
DETECTION OF PATHOGENS IN WASTEWATER AND SOIL BY TAQMAN ARRAY CARD (TAC) SYSTEM
}

\author{
Fahmida Sarkar ${ }^{1}$, Hamida Khanum*, Rimi Farhana Zaman, \\ Tahmina Ahmed ${ }^{1}$, Md. Khalid Eakbal Anik and Rashidul Haque ${ }^{1}$ \\ Department of Zoology, University of Dhaka, Dhaka-1000, Bangladesh
}

\begin{abstract}
The study was conducted in an a urban slum area of Dhaka city. The environmental samples (soil and water) were collected from Mirpur Bihari camp area including Madrasha camp, Muslim camp and ADC camp. The mai reas of sample collection were near the sewerage lines, chicken coop, goat house In the present investigation, out of 28 wastewater samples,

Aeromonas, Campylobacter, Vibrio cholerae, Blastocystis, Salr ella Trichuris, Ancylostoma, Plesiomonas, Bacteroides fragilis and Rota $>$ s hoge $>$ were recorded. In wastewater samples, $14.29 \%$ had single infect n, $1 \%$ double infection, whereas, observation on 20 soil samples by Th rs $\mathrm{m}$, tolal 12 types of pathogens were recorded such as Shigella, Ae onas, Can lobacter, Vibrio cholerae, Blastocystis, Salmonella, Plesiomonas, clo bs fragilis and Rota virus including Entamoeba sp., Ancylostoma and arissp.

Key words: Soil, Water, Wastewater, $\mathrm{P}$

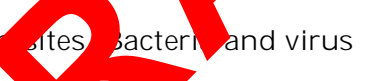

The prevalence of intestip po site $\mathrm{h}$ Bangladesh is very high. Parasitic infestation is a common heal pro $\mathrm{cm}$ around the globe especially in the developing countries wbic poso a continual and unacceptable threat to the well-being of million of po le in the tropics and subtropics; the cost of parasites in terms of man misery and economic loss is incalculable (Cox 2002, Mondal e 1. 20. In Bangladesh, infestation with protozoa and helminthes suc a Giardia intestinalis, Ascaris lumbricoides, Entamoeba histolytica a Th puris trichuira are major public health problem both in rural and urb a as with wide spread endemically. It was stated that health problems rela to diarrhea and helminthes are mostly water borne (Kramer et al. 1998, Sultana et al. 2007, Krkoset et al. 2016).

Intestinal parasitic infections are among the most common infections worldwide. Most intestinal parasites are heterogeneously distributed in host populations; according to a frequently quoted estimate, $20 \%$ of hosts harbor $80 \%$ of the intestinal helminthes. Adolescents and children are at high risk of

*Author for correspondence: <hamida_khanum@yahoo.com> licddrb, Mohakhali, Dhaka-1212, Bangladesh.

(c) 2018 Zoological Society of Bangladesh DOI: http://dx.doi.org/10.3329/bjz.v46i2.39046 
parasitic infection because of their behavioral aspects, general hygiene knowledge, socio-economic status (SES), environmental contamination, etc. The intestinal parasite may present asymptotically or may cause mild or severe diseases, generally producing symptoms like abdominal pain and vomiting. Besides this there are other symptoms like anorexia, nausea, diarrhea, indignation etc. Some of them may produce severe clinical manifestation like anemia, obstruction, perforation of gastrointestinal tract through peptic ulcer which causes secondary infection of bacteria (Greenberg and Estes 2009, Hudson 2002, Khanum et al. 2008). In Bangladesh, one in 30 ahildren die of diarrhea or dysentery by his or her fifth birthday. In Bangladesh one third of the total child death burden is due to diarrhea (Haque et al. 2

In Bangladesh, incidence of intestinal parasites is hig di to moist, hot climate, poor hygienic habit, ignorance, poverty and 1 th mporance in the lack of health education. Various studies have b o r out to find the prevalence of intestinal parasites in different rura d urban areas in Bangladesh. But the prevalence rate varied fro the to place. The findings of the present investigation will also help in den ny awareness among the people infected with parasites (Khanum ca 200 ). In Bangladesh intestinal parasitic infestation endemically wide cover due to low standard of living condition, poor personal hygi ra ces (Khanum et al. 2008).

y. This area wa selv as the living condition is unhygienic and impoverished child mos $y$ affected by diarrheal disease than the others. The majority of inha ants of the Mirpur site are of Bihari ethnic origin. This site is ns populated with more than one lakh people. The environmer sa ples, (soil and water) were collected from Mirpur Bihari camp area ine dir M asha camp, Muslim camp and ADC camp. Samples of soil and water collected from the areas where children had diarrhea often through diarrhea surveillance system at this site conducted by ICDDR, B. Moreover, the main areas of sample collection were near the sewerage lines, chicken coop, goat house etc.

Soil samples were collected from the site by a spatula in a falcon tube $(5 \mathrm{mg})$ and the water samples were collected from the site by handled pot $(5 \mathrm{ml})$ and kept in zip lock water pack. The study period was July, 2016 - June, 2017. Total 48 samples were collected ( 28 water and 20 soil samples) from Mirpur. Samples were examined by TaqMan Array Card (TAC) system. Soil samples that were collected from near the sewerage line were muddy as they were mixed with 
sewerage water and other samples that were collected from near the chicken coop and goat house were silty and dry. Wastewater samples were collected from sewerage line was muddy (Table 1).

Table 1. The places and types of collected soil samples

\begin{tabular}{lll}
\hline Sample & Collection area & Nature \\
\hline \multirow{3}{*}{ Soil } & Near sewerage line & Muddy \\
& Near goat house & Silt \\
\multirow{2}{*}{ Wastewater } & Near chicken coop & Silt \\
& Sewerage line & Muddy
\end{tabular}

RESULTS AND DISCUSSION

In the present observation on wastewater samples b system, total ten types of pathogens were recorded such as Shigella, on nan, Campylobacter, Vibrio cholerae, Blastocystis, Salmonella, Plesio nas, bu eroides fragilis and Rota virus including Entamoeba sp. Out of 28 at amples, 4 (14.29\%) had single infection and $24(85.71 \%)$ double ; tion $6(57.71 \%)$ triple infection, $20(71.42 \%)$ quadruple infection with fr di font opecies. The presence of five or more parasite species at a time in a se hust was considered as multiple infections and thus $12(42.86 \%)$ a $1 \mathrm{lt}$ - infection. Among 3 study areas, the single infection was highly valer (33.33\%) near Muslim camp, lowest $(0 \%)$ in both Madrasha camp na camp. Double, triple and quadruple infections were highest (1 \% $\%$ th Madrasha camp and ADC camp, whereas, lowest $(66.66,33.33$ d $33 \%$ ) in Muslim camp. Multiple infections were found highest (100 ADQ camp and lowest (33.33 and 33.33\%) in both Madrasha camp Mus, camp (Table 2).

Observation n samples by TAC system: In the present observation on soil sample 1 C system, total 12 types of pathogens were recorded such as Shigella "er non Campylobacter, Vibrio cholerae, Blastocystis, salmonella, Plesiomonas, cteroides fragilis and Rota virus including Entamoeba sp., Ancylostoma sp. and Trichuris sp. (Table 3).

Out of 20 soil samples, there was no single infection (0\%) while, 20 (100\%) double infection, $20(100 \%)$ triple infection, $16(80 \%)$ quadruple infection with four different species. The presence of five or more parasite species at a time in a single host was considered as multiple infections, 12 (60\%) had such multiple infection. Among 3 study areas (Muslim camp, Madrasha camp and ADC camp) no single infection was found. Double and triple infection were highest (100\%) among 3 study areas (Madrasha camp, ADC camp and Muslim camp). 
Quadruple and multiple infections were found highest (100\%) in both ADC camp and Muslim camp and lowest (66.66 and 33.33\%) in Madrasha camp (Table 4).

Table 2. Prevalence of pathogensin 28 wastewater samples

\begin{tabular}{|c|c|c|c|}
\hline Pathogen & $\begin{array}{l}\text { Number of tested } \\
\text { water samples }\end{array}$ & $\begin{array}{c}\text { Number of positive } \\
\text { samples }\end{array}$ & $\begin{array}{c}\text { Prevalence } \\
(\%)\end{array}$ \\
\hline Entamoeba & 28 & 20 & 71.42 \\
\hline Shigella & 28 & 8 & 28.57 \\
\hline Aeromonas & 28 & 16 & 57.14 \\
\hline Campylobacter & 28 & 24 & \\
\hline Vibrio cholerae & 28 & 12 & \\
\hline Blastocystis & 28 & 8 & \\
\hline Bacteroides fragilis & 28 & 8 & \\
\hline Adenovirus & 28 & 4 & \\
\hline Sapovirus & 28 & 4 & \\
\hline Plesiomonas & 28 & & 14.29 \\
\hline Pathogen & $\begin{array}{l}\text { Number of testec } \\
\text { soil samples }\end{array}$ & & $\begin{array}{c}\text { Prevalence } \\
\text { (\%) }\end{array}$ \\
\hline Entamoeba & 20 & 16 & 80 \\
\hline Shigella & & 4 & 20 \\
\hline Aeromonas & & 12 & 60 \\
\hline Campylobacter & & 20 & 100 \\
\hline Vibrio cholerae & & 16 & 80 \\
\hline Blastocystis & & 8 & 40 \\
\hline Salmonella & & 4 & 20 \\
\hline Ancylostoma & & 8 & 40 \\
\hline Trichuris sp. & 20 & 4 & 20 \\
\hline Plesiomonas & 20 & 12 & 60 \\
\hline Bacteroic & 20 & 4 & 20 \\
\hline Rota viru & 20 & 4 & 20 \\
\hline
\end{tabular}

Diarrhea was acquired from food or water that has been contaminated by stool, or directly from another person who is infected. Environmental conditions also make human beings vulnerable to parasites, and 1000 of people in developing countries live in below standard condition like, lacking safe water supplies and proper sanitation. Under these conditions parasitic diseases are common due to environmental pollution by human and animal excreta (Victora et al. 1993). So, overcrowding, lack of personal hygienic and sanitary conditions of the area, contaminated drinking water, may be responsible for higher 
Table 4. Prevalence of different double infections in total wastewater samples

\begin{tabular}{|c|c|c|c|}
\hline Pathogen & $\begin{array}{c}\text { Total no. of soil } \\
\text { samples } \\
\text { examined }\end{array}$ & $\begin{array}{c}\text { No. of positive } \\
\text { samples with two } \\
\text { parasites }\end{array}$ & $\begin{array}{c}\text { Prevalence } \\
\text { (\%) }\end{array}$ \\
\hline Cryptosporidium + Entamoeba & 28 & 12 & 42.86 \\
\hline Cryptosporidium + Campylobacter & 28 & 12 & 42.86 \\
\hline Cryptosporidium + Aeromonas & 28 & 8 & 28.57 \\
\hline Cryptosporidium + Blastocystis & 28 & 8 & 28.57 \\
\hline Cryptosporidium + Shigella & 28 & 4 & 14.29 \\
\hline Entamoeba + Campylobacter & 28 & 20 & 71.42 \\
\hline Entamoeba + Blastocystis & 28 & 12 & 42.86 \\
\hline Entamoeba + Aeromonas & 28 & & .14 \\
\hline Entamoeba + Plesiomonas & 28 & & 14.29 \\
\hline Entamoeba + Sapovirus & 28 & & 14.29 \\
\hline Entamoeba + Adenovirus & 28 & & 14.29 \\
\hline Entamoeba + Virio cholera & 28 & & 42.86 \\
\hline Entamoeba + Shigella & 28 & 8 & 28.57 \\
\hline Entamoeba + Bacteroides fragilis & & 4 & 14.29 \\
\hline Campylobacter + Aeromonas & & 16 & 57.14 \\
\hline Campylobacter + Plesiomonas & & 4 & 14.29 \\
\hline Campylobacter + Vibrio cholerae & & 8 & 28.57 \\
\hline Campylobacter + Sapovirus & & 4 & 14.29 \\
\hline Campylobacter + Shigella & & 8 & 28.57 \\
\hline Campylobacter + Blastocyst & 28 & 8 & 28.57 \\
\hline Campylobacter + & 28 & 8 & 28.57 \\
\hline Vibrio cholerae + & 28 & 12 & 42.86 \\
\hline Vibrio choler & 28 & 4 & 14.29 \\
\hline Vibrio chole & 28 & 8 & 28.57 \\
\hline Vibrio choler & 28 & 4 & 14.29 \\
\hline Vibrio chole & 28 & 8 & 28.57 \\
\hline ides fragili & 28 & 8 & 28.57 \\
\hline Shigella + Sapo & 28 & 4 & 14.29 \\
\hline Shigella + Adenovirus & 28 & 4 & 14.29 \\
\hline Shigella + Plesiomonas & 28 & 4 & 14.29 \\
\hline Shigella + Bacteroides fragilis & 28 & 8 & 28.57 \\
\hline Blastocystis + Aeromonas & 28 & 8 & 28.57 \\
\hline Blastocystis + Plesiomonas & 28 & 4 & 14.29 \\
\hline Blastocystis + Bacteroides Fragilis & 28 & 8 & 28.57 \\
\hline Blastocystis + Adenovirus & 28 & 4 & 14.29 \\
\hline
\end{tabular}


prevalence of infections. However, the prevalence of the parasites the present study was contradictory with previous studies (Ngan et al. 1992, Verle et al. 2003). This difference may be due to diagnostic techniques.

About 1.7 to 5 billion cases of diarrhea occur per year (Abdelmalak and Doyle 2013). Diarrhea is a major public health problem which is most common in developing countries, including Bangladesh where young children get diarrhea on average three times a year (WHO 2013). Walker et al. (2013) estimated high rate of diarrhea mortality among young children in low and middle income countries. Diarrheal disease may have a negative impact on both physical fitness and mental development. "Early childhood alnutrition resulting from any cause reduces physical fitness and wo tivity in adults, and diarrhea is a primary cause of childhood mo nu ion (Guerrant et al.1992, WHO 1987).

The most common cause is an infection of in est. s due to either a virus, bacteria, or parasite; a condition known as gaso teritis. According to Wright et al. (1991) environmental facto prevalence of diarrheal causing agent. They stated that housc acture (28\%), water usage $(24 \%)$, toilet and bathing area $\left(12^{\circ}\right.$, hima management (11\%), food preparation area (10\%), hygiene (8\%) wa water management $(6 \%)$ also influence their presence which is 5 to findings of the present study.

In the present study, soil sam s we also collected from chicken coop, goat house and out of total 20 soil $\mathrm{m}_{\mathrm{H}}$ s were positive for Cryptosporidium spp. (14.29\%). There was no sle tion 0\%, 100\% double infection, 100\% triple infection, $80 \%$ quadr ection and $60 \%$ had multiple infections. Water samples were was er. O $>$ of total 28 water samples 24 samples were positive for $\mathrm{Cry}$ osporm $(85.71 \%)$. In the present study, in soil and wastewater sar le. otavirus, adenovirus, Campylobacter spp., Salmonella spp. and Shigell op. vero lso found. There was $14.29 \%$ single infection, $85.71 \%$ double $7.71 \%$ triple infection, $71.42 \%$ quadruple infection and $42.86 \%$ mo infections (Tables 5, 6, 7).

There are many causes of infectious diarrhea, which include viruses, bacteria and parasites (Navneethan and Gianella 2008, Abrahams 2002). Along with Cyptosporidium spp. and Giardia lamblia, rota virus is the most common cause in children under five years old (Greenberg and Estes 2009) and Adenovirus ( Uhnoo et al. 1990) cause a significant number of infections (Rose 1990, Rose et al. 1991). Campylobacter spp. is a common cause of bacterial diarrhea but infections by Salmonella spp., Shigella spp. are also a frequent cause (Viswanathan et al. 2009). Soil ingestion is also associated with child diarrhea. Environmental characteristics and behavioral practices have been 
Table 5. Prevalence of different triple infections in total wastewater samples

\begin{tabular}{|c|c|c|c|}
\hline Pathogen & $\begin{array}{l}\text { Total no. of soil } \\
\text { samples examined }\end{array}$ & $\begin{array}{l}\text { No. of positive samples } \\
\text { with three parasites }\end{array}$ & $\begin{array}{l}\text { Prevalence } \\
\text { (\%) }\end{array}$ \\
\hline $\begin{array}{l}\text { Cryptosporidium + Entamoeba }+ \\
\text { Blastocystis }\end{array}$ & 28 & 8 & 28.57 \\
\hline $\begin{array}{l}\text { Cryptosporidium + Entamoeba + } \\
\text { Campylobacter }\end{array}$ & 28 & 16 & 57.14 \\
\hline $\begin{array}{l}\text { Cryptosporidium + Entamoeba + } \\
\text { Shigella }\end{array}$ & 28 & 4 & 14.29 \\
\hline $\begin{array}{l}\text { Cryptosporidium + Entamoeba }+ \\
\text { Aeromonas }\end{array}$ & 28 & 4 & 14.29 \\
\hline $\begin{array}{l}\text { Entamoeba + Campylobacter } \\
+ \text { Blastocystis }\end{array}$ & 28 & 12 & 42.86 \\
\hline $\begin{array}{l}\text { Entamoeba }+ \text { Campylobacter }+ \\
\text { Aeromonas }\end{array}$ & 28 & & 57.14 \\
\hline $\begin{array}{l}\text { Entamoeba }+ \text { Campylobacter }+ \\
\text { Vibrio cholerae }\end{array}$ & 28 & & 42.86 \\
\hline $\begin{array}{l}\text { Entamoeba }+ \text { Shigella }+ \\
\text { Bacteroides fragilis }\end{array}$ & 28 & & 28.57 \\
\hline $\begin{array}{l}\text { Entamoeba + Adenovirus + } \\
\text { Aeromonas }\end{array}$ & 28 & & 14.29 \\
\hline Entamoeba + Adenovirus $+P$ & 28 & 4 & 14.29 \\
\hline $\begin{array}{l}\text { Entamoeba }+ \text { Aeromonas }+ \\
\text { Plesiomonas }\end{array}$ & & 4 & 14.29 \\
\hline $\begin{array}{l}\text { Entamoeba + Aeromonas }+ \\
\text { Sapovirus }\end{array}$ & & 4 & 14.29 \\
\hline $\begin{array}{l}\text { Entamoeba }+ \text { Aeromonas }+ \text { Vibrio } \\
\text { cholerae }\end{array}$ & & 12 & 42.86 \\
\hline $\begin{array}{l}\text { Shigella + Campylobacter }+ \\
\text { Sapovirus }\end{array}$ & & 4 & 14.29 \\
\hline $\begin{array}{l}\text { Shigella }+ \text { Campylobacter }+ \\
\text { Adenovirus }\end{array}$ & 28 & 4 & 14.29 \\
\hline $\begin{array}{l}\text { Shigella + Campy } \\
\text { Blastocystis }\end{array}$ & 28 & 8 & 28.57 \\
\hline $\begin{array}{l}\text { Shigella }+ \text { Blast } \\
\text { Bacteroides frig }\end{array}$ & 28 & 8 & 28.57 \\
\hline $\begin{array}{l}\text { Shigella }+ \text { A6 } \\
\text { Plesiomopas }\end{array}$ & 28 & 4 & 14.29 \\
\hline $\begin{array}{l}\text { Blastocys } \\
\text { Vibrio cholerat }\end{array}$ & 28 & 8 & 28.57 \\
\hline $\begin{array}{l}\text { Blastocystis }+ \text { Aeromonas }+ \\
\text { Bacteroides fragilis }\end{array}$ & 28 & 8 & 28.57 \\
\hline $\begin{array}{l}\text { Blastocystis }+ \text { Aeromonas }+ \\
\text { Plesiomonas }\end{array}$ & 28 & 4 & 14.29 \\
\hline $\begin{array}{l}\text { Blastocystis + Adenovirus + } \\
\text { Plesiomonas }\end{array}$ & 28 & 4 & 14.29 \\
\hline $\begin{array}{l}\text { Blastocystis + Sapovirus + Vibrio } \\
\text { cholera }\end{array}$ & 28 & 4 & 14.29 \\
\hline $\begin{array}{l}\text { Campylobacter }+ \text { Vibrio cholera }+ \\
\text { Aeromonas }\end{array}$ & 28 & 12 & 42.86 \\
\hline $\begin{array}{l}\text { Adenovirus }+ \text { Plesiomonas }+ \\
\text { Aeromonas }\end{array}$ & 28 & 4 & 14.29 \\
\hline
\end{tabular}


Table 6. Prevalence of different quadruple infections in total wastewater samples

\begin{tabular}{|c|c|c|c|}
\hline Pathogen & $\begin{array}{c}\text { Total no. of soil } \\
\text { samples } \\
\text { examined }\end{array}$ & $\begin{array}{l}\text { No. of positive } \\
\text { samples with } \\
\text { four parasites }\end{array}$ & $\begin{array}{l}\text { Prevalence } \\
\text { (\%) }\end{array}$ \\
\hline $\begin{array}{l}\text { Cryptosporidium + Entamoeba + Campylobacter } \\
+ \text { Blasocystis }\end{array}$ & 28 & 8 & 28.57 \\
\hline $\begin{array}{l}\text { Cryptosporidium + Entamoeba + Campylobacter } \\
+ \text { Aeromonas }\end{array}$ & 28 & 8 & 28.57 \\
\hline $\begin{array}{l}\text { Cryptosporidium + Entamoeba + Campylobacter } \\
+ \text { Vibrio cholera }\end{array}$ & 28 & 4 & 14.29 \\
\hline $\begin{array}{l}\text { Cryptosporidium }+ \text { Entamoeba }+ \text { Bacteroides } \\
\text { fragilis + Shigella }\end{array}$ & 28 & 4 & 14.29 \\
\hline $\begin{array}{l}\text { Cryptosporidium }+ \text { Entamoeba }+ \text { Aeromonas }+ \\
\text { Sapovirus }\end{array}$ & 28 & & \\
\hline $\begin{array}{l}\text { Cryptosporidium }+ \text { Blastocystis }+ \text { Shigella }+ \\
\text { Vibrio cholerae }\end{array}$ & 28 & & 14.29 \\
\hline $\begin{array}{l}\text { Entamoeba + Blastocystis + Campylobacter + } \\
\text { Sapovirus }\end{array}$ & 28 & & 14.29 \\
\hline $\begin{array}{l}\text { Entamoeba + Blastocystis + Campylobacter + } \\
\text { Adenovirus }\end{array}$ & & 4 & 14.29 \\
\hline $\begin{array}{l}\text { Entamoeba }+ \text { Blastocystis }+ \text { Shigella }+ \\
\text { Bacteroides fragilis }\end{array}$ & & 8 & 28.57 \\
\hline $\begin{array}{l}\text { Entamoeba + Blastocystis }+ \text { Aeromonas } \\
\text { Plesiomonas }\end{array}$ & & 4 & 14.29 \\
\hline $\begin{array}{l}\text { Entamoeba + Campylobacter } \\
\text { Vibrio cholerae }\end{array}$ & 28 & 8 & 28.57 \\
\hline $\begin{array}{l}\text { Shigella }+ \text { Campylobacter }+ \\
\text { Bacteroides fragilis }\end{array}$ & 28 & 4 & 14.29 \\
\hline $\begin{array}{l}\text { Shigella + Campylobact } \\
\text { Blastocystis }\end{array}$ & 28 & 8 & 28.57 \\
\hline $\begin{array}{l}\text { Shigella + Plesion } \\
\text { cholerae }\end{array}$ & 28 & 4 & 14.29 \\
\hline $\begin{array}{l}\text { Campylobacter }+1 \\
\text { Vibrio cholers }\end{array}$ & 28 & 4 & 14.29 \\
\hline
\end{tabular}

identified a factors for diarrhea in developing countries as people living in slums or in the rower socio-economic stratum have little or no access to services such as water sanitation, proper drainage and waste disposal and as a result also become polluted by diarrhea causing agents. Worldwide in 2004, approximately 2.5 billion cases of diarrhea occurred, which resulted in 1.5 million deaths among children under the age of five. Greater than half of these were in Africa and South Asia (WHO 2009). This is lower from a death rate of 4.5 million in 1980 for gastroenteritis (Mandell et al. 2004). Diarrhea remains the second leading cause of infant mortality (16\%) after pneumonia (17\%) in this age group (WHO 2009). 
Table 7. Prevalence of different multiple infections in total wastewater samples

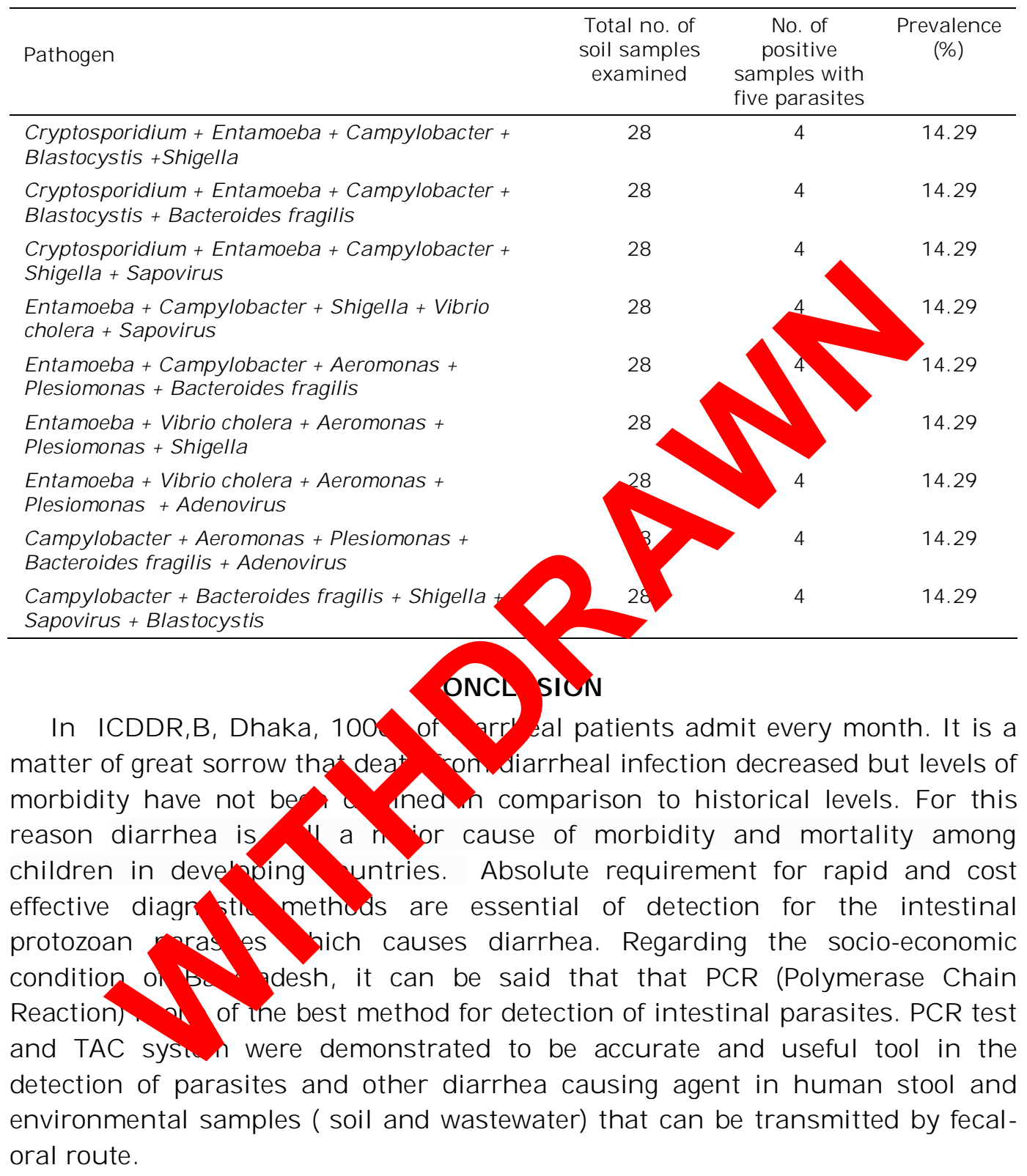

\section{LITERATURE CITED}

ABDELMALAK, B. and DOYLE, J. 2013. Anesthesia for otolaryngologic surgery. Cambridge University Press. pp. 282-287.

ABRAHAMS, P. W. 2002. Soils: Their implications to human health. The science of the total Environment 291: 1-32. 
COX, F. E. G. 2002. History of human parasitology.Clinical Microbiology Review 15(4): 595-612.

GREENBERG, H.B. and ESTES, M.K. 2009. Rotaviruses: from pathogenesis to vaccination. Gastroenterology 136(6): 1939-51.

GUERRANT, R. L., SCHORLING, J. B., MCAUlifFE, J. F., and DE SOUZA, M. A. 1992. Diarrhea as a cause and an effect of malnutrition: diarrhea prevents catch-up growth and malnutrition increases diarrhea frequency and duration. The American Journal of Tropical Medicine and Hygiene 47(2): 28-35.

HAgUE, R., MONDAL, D., KIRKPATRICK, B.D., AKTHER, S., FARR, B. M., SACK, R. B. and PETRI. W. A. 2003. Epidemiologic and clinical characteristics of acute diarrhea with emphasis on Entamoeba histolytica infections in preschool children in an urban slum of Dhaka, Bangladesh. American Journal of Tropical Medicine and Hygiene 69: 398-405.

HUDSON, P.J. 2002. The Ecology of Wildlife Diseases. Oxford University Pres

KHANUM, H., AHMED, S., UDDIN, M. H. RAHMAN, A. B. M.M. DEY, R. K ND RHAIVA, R. 2008. Prevalence of intestinal parasites and anaemia among the slup nale hildi in Dhaka city. Dhaka Univ. J. Biol. Sci. 17(2): 137-145.

KRAMER, M. H., HERWALDT, B. L., CRAUN, G. F., CALDERON, A P J NANER, D. D. 1998. Surveillance for waterborne-disease outbreaks-United ates, 195994. Morb Mort.Weekly Report. 45(SS-1): 1-33.

KRKOSEK, W., REED, V. and GAGNON, G. A.2016 stozsin risks for surface drinking water supplies in Nova Scotia, Canada. J. Wat Heg h 14 155-66.

MONDAL, D., MINAK,J., ALAM, M. and PETRI, W. A2. Atribution of enteric infection, altered intestinal barrier function, and mater in to infant malnutrition in Bangladesh. Clinical Infectious Diseases 54(2): 1

NAVANEETHAN, U. and GIANNELLA A. chanisms of infectious diarrhea. Nature Clinical Practice Gastroenterology \& Hepato y 5 637-47.

NGAN, P. K., KHANK, N. G., TQ C. BUY, P. P., ANH, D. N., THUY, H. T.1992. Persistent diarrhea in Vietnamese cildre preliminary report. Acta Paediatr 381:124-6.

ROSE, J. B. 1990. Eme no sues fo, the microbiology of drinking water. Water Eng. Manage 29 : 23-16.

ROSE, J. B., HAS C. REGLI, S. 1991. Risk assessment and control of waterborne giardiasis. Am. J. Pu He h 8. 709-713.

SULTANA. , K Alv and HAQUE, R. 2007. Comparative study of gal/galnac lectin in response to Entar ho historytica infection among the preschool children in Bangladesh. Bangladesh $J$. Zool. 35(1): So 8 .

UHNOO, I., SVENSSON, L. and WADELL, G. 1990. Enteric adenoviruses. Baillière's Clinical Gastroenterology 4(3): 627-42.

VERLE, P., KONGS, A., DE, N.V., THIEU, N.Q., DEPRAETERE, K., KIM, H.T. and DORNY, P. 2003. Prevalence of intestinal parasitic infections in northern Vietnam. Tropical Medicine of International Health 8: 961-964.

VICTORA, C.G., HUTTLY, S.R. and FUCHS, S. 1993. International differences in clinical patterns of diarrheal deaths: a comparison of children from Brazil, Senegal, Bangladesh, and India. J. Diarrh. Dis. Res. 11: 25-29. 
VISWANATHAN V.K, HODGES, K. AND HECHT, G. 2009. Enteric infection meets intestinal function how bacterial pathogens cause diarrhea. Nature Reviews Microbiology 7(2): 110-12.

WALKER, C. L., RUDAN, I., LIU, L., NAIR, H., THEODORATOU, E., BHUTTA, Z. A., O'BRIEN, K. L., CAMPBELL, H. and BLACK, R, E. 2013. Global burden of childhood pneumonia and diarrhea. Lancet. 381(9875): 1405-1416.

WORLD HEALTH ORGANIZATION. 1987. Health guidelines for the use of wastewater in agriculture and aquaculture. WHO Report: Scientific group meeting, November $18^{\text {th }}-23^{\text {th }}$.

WORLD HEALTH ORGANIZATION 1994. Bench Aids for Diagnosis of Intestinal Parasites. Geneva: World Health Organization.

WORLD HEALTH ORGANIZATION. 2013. Diarrheal disease. Fact sheet.www.who.j^t/mediacentre/ factsheets/fs330.

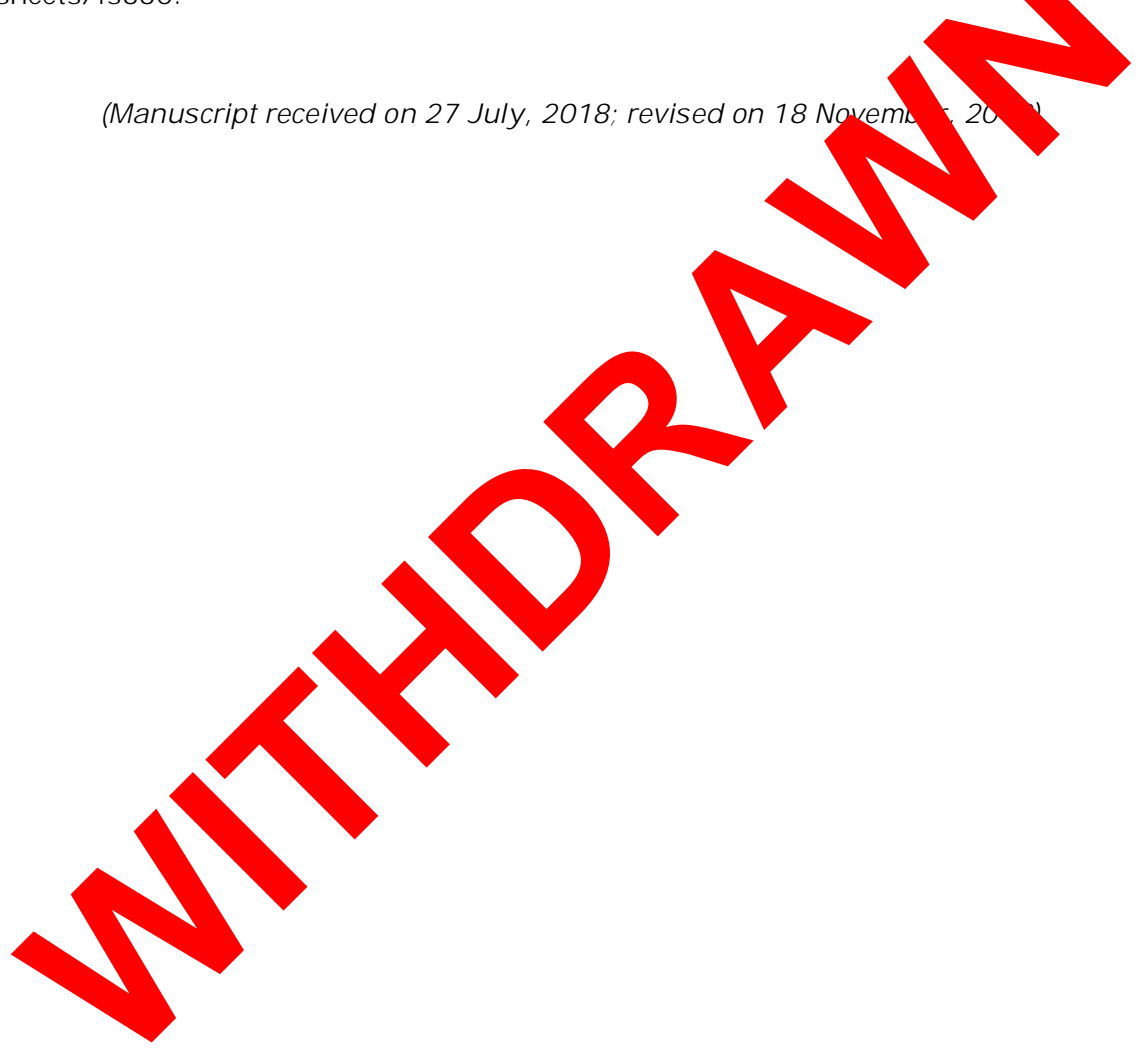

